\title{
Pregação e cavalaria no processo de expansão da cristandade latina: o papel da Ordem da Milícia de Ramon Llull (1232-1316)
}

\author{
Preaching and knighthood in the process of expansion of Latin Christendom: \\ The role of the Ramon Llull's Orde de la Milícia
}

André Luis Pereira Miatello*

\begin{abstract}
Resumo
Este artigo reexamina o posto de Ramon Llull na história da pregação da Baixa Idade Média ocidental, tendo em vista as novas abordagens sobre o tema da pregação e sua relação com o espaço do político. Discute-se também o projeto luliano de fundação de uma Ordem militar unificada cuja finalidade era dar suporte à pregação e conversão do infiel consoante a função eclesial da cavalaria cristã. O estudo da concepção luliana de conversão do muçulmano exige uma posição metodológica cuidadosa, uma vez que envolve sentimentos ligados à alteridade, à violência e à intolerância. Diante disso, evitar-se-á qualquer dissociação entre discurso e seus enunciadores, certo de que a violência se origina das relações sociais, não de pensamentos coletivos transistóricos descolados de uma específica situação espaciotemporal. As obras lulianas são apologéticas e polemistas e, por isso, não podem ser tomadas por descrições imediatas de uma suposta mentalidade intolerante ou persecutória, característica de um medievo anárquico, mas, ao contrário, registros, isto é, mediações em que certa retórica está sendo mobilizada para a promoção de interesses de certos sujeitos em detrimento de outros; é um jogo de poder em que alguns sujeitos se autolegitimam enquanto procuram deslegitimar os outros.
\end{abstract}

Palavras-chave: Vida religiosa, pregação, violência, Idade Média, cavalaria

\begin{abstract}
This article re-examines the role played by Ramon Llull in the history of preaching in the Western Middle Ages taking into consideration the new approaches in sermon studies and politics. Also under discussion is the Llull's project to create a new unified military Order whose purpose is to support the preaching and the conversion of the infidel according to the ecclesiastical task of the Christian knighthood. The study of the Lullian' efforts to converting Muslims into Christian faith demands an accurate methodology since it can be related to alterity, violence and intolerance. In light of this, any dissociation between discourse and its enunciators will be avoided, certain that violence originates in social relations, not in transhistorical collective mentality detached from a specific space-time situation. The Lullian works are apologetic and polemical, therefore, they cannot be taken by a neutral account of a supposed intolerant or persecutory culture, characteristic of an anarchic medieval era, but rather, they are records, that is, mediations by which a certain rhetoric can be mobilized to defend the interests of certain individuals subjects in detriment of others; it is a power game in which some subjects self-legitimize themselves as they seek to delegitimize others.
\end{abstract}

Key-words: Religious life, preaching, violence, Middle Ages, knighthood

\footnotetext{
Artigo submetido em 08 de setembro de 2017 e aprovado em 02 de dezembro de 2017.

${ }^{*}$ Doutor em História Social pela Faculdade de Filosofia, Letras e Ciências Humanas da Universidade de São Paulo (2010). Professor de História Medieval do Departamento de História da UFMG. País de Origem: Brasil. E-mail: andremiatello@gmail.com
} 


\section{0 estado da questão}

Quando Ramon Llull ${ }^{1}$ começou a escrever suas obras, pelos idos de 1270, os milites cristãos latinos já contavam com, pelo menos, 500 anos de história e orgulhavam-se de ter uma tradição narrativa, cultural, religiosa e bélica já bastante desenvolvida. Durante estes seis séculos, não faltaram cronistas e historiadores, prosadores e poetas, hagiógrafos e jograis para, de um lado, ilustrar as façanhas heroicas dos valorosos guerreiros e, de outro, vituperar os defeitos daqueles infelizes covardes que desertaram ou traíram seus nobres ideais. Graças a este patrimônio, a cavalaria dos tempos de Llull já era uma instituição assentada socialmente, autorizada pela lei e sacramentalizada pela fé; era, ao mesmo tempo, uma realidade e um sonho, pois sabemos que esta instituição militar originou-se de diferentes matrizes e percorreu sendas diversas até encontrar-se numa história mais ou menos comum entre os séculos XII e XIII (BARTHÉLEMY, 2010; FLORI, 2005).

Entre a geração de Ramon Llull e aquela de Carlos Martel, em 732, solidificouse a convicção de que a cristandade era, a um só tempo, a fraternidade de todos os crentes em Cristo e, por isso, a extensão visível de seu corpo místico, mas também o espaço delimitado pelas fronteiras com os reinos muçulmanos, pagãos e cismáticos (IOGNA-PRAT, 2002, p. 1). A cristandade parecia uma ilha rodeada por um mar de descrença e de erro; os cristãos gregos, na medida em que negavam a comunhão com a fé romana, estavam igualmente de fora e, por isso, a cristandade afirmava-se latina, capitaneada, não sem conflito, pela auctoritas pontifícia e pela potestas régia. Em

\footnotetext{
${ }^{1}$ Ramon Llull (ou Raimundo Lúlio, na versão vernácula) nasceu na cidade de Palma (Ilha de Maiorca) por volta de 1232; era um tempo conturbado para a ilha, pois entre 1229 e 1232, os aragoneses e catalães, capitaneados por Jaime I, o Conquistador, travaram uma grande guerra contra os maiorquinos muçulmanos com o fito de tomar o poder e anexar o território. Iniciava-se, assim, um processo sóciopolítico de transferência populacional e de reorganização social e religiosa. Filho de repobladores ligados à monarquia cruzadista de Jaime I, Ramon Llull compartilhou da visão comum de que o islam era invasor, estranho e de que formava uma sociedade inimiga. Quando de seu despertar religioso (ou conversão), em 1263, Llull tornou-se mais fortemente refratário à presença muçulmana e passou a dedicar o melhor de suas energias para a conversão dos chamados infiéis. Sua vasta produção livresca conta 250 obras escritas em vulgar catalão, latim e árabe; nestes livros, Llull elabora sua apologética católica antiislâmica a partir da filosofia, teologia e literatura, sempre procurando lapidar aquilo que chamou de 'A Arte de Encontrar a Verdade' (Ars inveniendi veritatem), que consistia num método racional de expor a fé cristã aos muçulmanos (e judeus) e de convencê-los da verdade da fé cristã católica. Neste intuito, percorreu cortes e cúrias, cidades e reinos a fim de encontrar apoiadores e colaboradores para o projeto de fundação de escolas missionárias de línguas orientais para pregadores latinos que iriam para a terra dos infiéis; também procurou convencer os papas e reis da necessidade de se recuperar a Terra Santa pela prévia conquista da Península Ibérica, Norte de África e Egito, até chegar à Palestina e Jerusalém. Morreu em 1316, em altomar, quando retornava fracassado de uma de suas várias tentativas de pregar e converter os muçulmanos no Norte de África.
} 
Llull, a noção de fronteira adquire toda a sua força de diferença geográfica, cultural e, mais do que isso, civilizacional: era o limite entre o verdadeiro e o falso, o bom e o ruim. E nisso ele não estava sozinho, já que o século XIII ocidental conheceu uma volumosa torrente de tratadistas, pregadores, apologetas e polemistas que ressaltavam a ligação entre cristandade, cavaleiros, cruzadas e infiéis (MAIER, 2007; LEOPOLD, 1998).

De modo particular, nas regiões meridionais da cristandade latina, sobretudo no Languedoc e na Península Ibérica, os milites foram muito sensíveis à sua condição de protetores do espaço cristão contra o inimigo sarraceno, fato que os colocava numa situação eclesial diferenciada, uma vez que os guerreiros ajudavam a definir os contornos geográficos da comunidade cristã pela exclusão do outro não cristão, bem como contribuíam para "gerar o idêntico" (IOGNA-PRAT, 2016, p. 108), isto é, uma cultura cristã, militante e autoafirmativa, compartilhada por diversas comunidades étnicas.

Não nos esqueçamos de que estas regiões cristãs meridionais, desde o século VIII, sentiam-se ameaçadas pela presença islâmica e que, desde cedo, desenvolveuse, entre os meridionais latinos, a identificação dos muçulmanos como os inimigos de Cristo: dezenas de obras tratadísticas, exegéticas, literárias e artísticas foram compiladas para difundir esta ideia separatista e, em grande parte destas composições, os cavaleiros despontavam como os grandes baluartes da comunidade cristã anti-muçulmana, defensores do corpo místico de Cristo contra as forças do anticristo (PARDO PASTOR, 2005; FERRER MALLOL, 1998). A leitura de tais obras leva-nos a perceber melhor o quanto os cavaleiros meridionais foram objeto de uma gradativa intensificação de seu significado eclesial, ao longo dos séculos XII e XIII.

Os cartulários da Abadia de Saint-Victor de Marselha, na Provença, possuem alguns documentos que registram as investidas islâmicas na região, afetando, sobretudo, os domínios monásticos e episcopais. A Carta Liberalis, de 1005, registra alguns traços da tumultuosa relação entre cristãos e muçulmanos no Languedoc; 
esta carta é importante, porque ela é o documento que confere a isenção ao mosteiro, em relação ao patrimônio episcopal, e testifica a refundação desta comunidade monástica:

Tendo transcorridos muitos anos desde o passamento do piedosíssimo príncipe [Carlos Magno], Deus onipotente quis castigar o povo cristão [populus christianum] por meio da sevícia dos pagãos, um povo bárbaro irrompeu no reino, na parte da Provença, e cercando-a de todos os lados, a invadiu com fúria; conquistando os lugares fortificados, devastou todos os habitantes e destruiu muitas igrejas e mosteiros; e os lugares que, antes, eram deleitáveis, foram reduzidos à solidão; os lugares que haviam sido, até então, habitação de homens, tornou-se, depois disso, habitação de feras. E assim aconteceu que aquele mosteiro que, outrora, fora tão importante e famoso em toda a Provença foi arrasado e quase inteiramente reduzido a nada, até que o senhor Guilherme, de boa memória, e o senhor Honorato, bispo da referida cidade, e seu irmão, o senhor Guilherme, visconde, e seu filho, senhor Pôncio, bispo, que sucedeu a seu tio no episcopado, puseram fim à sublevação neste meio tempo. (GUÉRARD, 1857, tomo I, p. 19)².

Em que pese o modo demasiado genérico com que a carta se refere aos seguidores do Corão e aos estereótipos que reproduz (LUCKEN, 2004), nota-se que a compreensão identitária da população latina da Provença passa pela evidência de ser ou de pertencer a um "povo cristão" que, claro está, se remete ao projeto político arquitetado pelos carolíngios, não sem a participação dos papas de Roma, no caso, João XVIII (1004-1009), como vem referido, antes, na carta.

Algo parecido pode se encontrar numa missiva do papa Honório II (11241130) aos bispos da Provença, conservada no cartulário da Abadia de Saint Honorat de Lérins. Defendendo o suposto direito dos monges sobre algumas igrejas da região, o papa apresenta o seguinte quadro:

o nosso filho, o abade de Lérins, e seus monges, colocados diante das fauces dos Sarracenos, temendo o perigo dos sequestros, das cadeias e da morte, reclamaram de vós em lágrimas, pois vós presumistes tirar deles, violentamente, a igreja do castro que se chama Monasterium, com suas propriedades e igrejas, a igreja do castro de Rocabruna e a igreja de SaintTropez [...]. (MORRIS e BLANC, 1883, tomo I, p. 300).

\footnotetext{
${ }^{2}$ Quando as traduções presentes neste artigo não trouxerem o nome do tradutor é porque são de minha responsabilidade.
} 
Na demanda que o papa Honório apresenta aos bispos provençais, percebese que a presença muçulmana podia até provocar medo, mas os atores da violência eram, ao contrário, os próprios bispos. No entanto, este mosteiro, como aquele de Marselha, testemunha que, para além dos espaços ibéricos, a ameaça islâmica pairava principalmente sobre as igrejas e as casas monásticas, isto é, lugares de residência da maior parte dos homens de saber que, com suas penas e pergaminhos, construíram uma cultura histórica anti-muçulmana na qual a cavalaria se associava à defesa da Igreja e ao serviço de São Pedro.

Seja no Languedoc, no norte de Itália ou na Península Ibérica, grandes abadias e renomadas catedrais careciam, cada vez mais, do apoio dos milites para manter afastados os muçulmanos. Sabemos que era grande a quantidade de mosteiros e bispados que contavam com agrupamentos cavaleirescos agregados às casas eclesiásticas, na qualidade de vassalos ou, até mesmo, mercenários. Muitas destas casas, como acontecia com a Abadia de Lérins, dotavam seus milites de privilégios eclesiais, tornando-os membros externos, mas participantes, dos benefícios espirituais da casa monástica, inclusive, em alguns casos, compatíveis com a situação dos cruzados. Como discute Damien Carraz (2005, p. 46), tais iniciativas colaboravam para o aumento da consciência eclesial dos cavaleiros que, juntos, começaram a fundar confrarias de guerreiros ao redor destes lugares sagrados, protótipos das futuras Ordens monásticas militares.

Em âmbito ibérico, particularmente catalão, encontramos, para esta época, o caso da fundação de uma milícia permanente de cavaleiros dedicados à expulsão dos muçulmanos: trata-se da Militia Christi de Monreale, fundada pelo rei aragonês, Afonso I o Batalhador (1073-1134), e erigida como confraria cavaleiresca pelo sínodo dos bispos de Aragão. O documento que nos dá notícia desta fundação é a Carta do Arcebispo Guilherme de Aux (c.1124) pela qual os bispos confirmam a iniciativa régia e concedem à confraria dos Cavaleiros de Cristo, como são chamados, os dotes, 
privilégios e indulgências, bem como lhes outorgam plena participação na comunhão de bens espirituais, visíveis nas celebrações de missas em suas intenções3.

A aproximação entre a milícia permanente de Monreale e a Ordem do Templo, aprovada pela lei eclesiástica em 1120, é expressamente atestada pelo arcebispo; em outra passagem, ele reafirma: "Para isso acrescentou o rei que esta santa milícia fosse livre e isenta de todo tipo de servidão, nomeadamente a da quinta, de modo semelhante à milícia da confraria de Jerusalém [...]" (CRESPO, 2006a, p. 188). É ainda discutível o significado histórico desta aproximação, pois, como se pode deduzir, os cavaleiros de Monreale, diferentemente dos templários, não professavam votos religiosos, embora pudessem acolher clérigos como confrades, como sucedeu ao próprio Guilherme, arcebispo de Aux. No entanto, o estatuto laico dos cavaleiros não pode, aqui, desviar nossa atenção da insistência com que Guilherme qualifica a milícia, chamando-a "militia Dei", cuja sede se situava na recém-criada cidade de Monreale, e outros apelativos, como "sancta militia", usado duas vezes, "sancta societas", "societas ad serviendum Deo" e "sancta confraternitas". São termos de rápida associação ao âmbito sacro, de jurisdição mais eclesiástica do que régia. Tanto assim que, embora seja o rei e seus conselheiros a tomar a iniciativa da fundação, foi preciso um sínodo episcopal para dotar esta confraria cavaleiresca do estatuto de que ela pretendia gozar, isto é, de ser um grupo armado ao serviço da causa da Igreja.

Isso verifica-se, por exemplo, na intenção desta confraria de expulsar os muçulmanos de Aragão e de abrir uma nova rota de viagem para a Terra Santa que partisse do próprio reino. Em rápidas referências, o texto arquiepiscopal liga a missão da Militia Christi de Monreale aos objetivos dos templários e a associa aos privilégios eclesiásticos dos mesmos. Pascual Crespo (2006b, p. 39) interpreta esta fundação pelo seu viés político e estratégico de afirmação da monarquia aragonesa através da associação com os intentos cruzadísticos pontifícios, diminuindo seu

\footnotetext{
3 "[Afonso, corajoso e glorioso rei de Aragão] [...] decidiu erigir e constituir a militiam Xristi aos modos da de Jerusalém, pela qual, sob seu comando, serão debelados e vencidos todos os Sarracenos deste lado do mar, e abrir o caminho para se chegar a Jerusalém, segundo a vontade de Cristo". (CRESPO, 2006a, p. 187-188).
} 
aspecto religioso. Não consigo concordar inteiramente com ele. Finalidade política ou religiosa, a Milícia de Cristo ajudou a sedimentar a função eclesial da cavalaria, ligando-a diretamente à definição do espaço social cristão, em outros termos, à cristandade.

Muito se tem debatido sobre a chamada Reconquista ibérica, o que já nos deve pôr em alerta contra possíveis aproximações perigosas entre o nacionalismo do século XIX e os acontecimentos do período que aqui nos interessa (RÍOS, 2005). No entanto, a rivalidade e o enfrentamento entre cristãos e muçulmanos, em solo peninsular, alcançaram níveis paradoxais, sobretudo entre os séculos XI-XIII. De modo semelhante à compreensão dos monges provençais, encontra-se delineada, entre os cristãos ibéricos, a convicção de que a tomada das terras aos muçulmanos constituía um ato sagrado, pois, como afirma Carlos Ayala Martínez (2008), significava a recuperação da antiga igreja visigótica e, neste caso, lutar contra os muçulmanos equivalia a defender os direitos da Igreja.

Neste mesmo artigo, Carlos Ayala desenvolve uma avaliação ampla acerca da configuração dos reinos cristãos ibéricos, em que a proposta papal de combate ao inimigo muçulmano tornou-se, para tais reinos, possibilidade de alargamento territorial e aprofundamento dos laços políticos das monarquias que, sendo ou não vassalas da Sé Apostólica, se aproveitaram da cultura anti-muçulmana para ampliar seu raio de influência. A atividade eclesial de Ramon Llull insere-se neste período de definição dos limites do reino e da natureza do poder régio ibérico; insere-se também nos contornos da campanha pela conversão dos muçulmanos e pela retomada dos lugares santos do Oriente.

É aqui que pregação e cavalaria são equiparadas como estratégias de conquista cristã. Llull foi um homem de ação que não limitava o reino de Maiorca à Península Ibérica ou ao Languedoc, mas o pensava a partir do perímetro espiritual da cristandade e, por causa do significado militante da cristandade latina, ele empreendeu diversas iniciativas com o fito de maximizar a força moral, intelectual e 
militar da cristandade para instaurar, se possível definitivamente, o reinado social de Cristo na Terra. É dentro desta perspectiva que se compreende, inclusive, o lugar da pregação na obra de Ramon Llull. Diante desse quadro descritivo, pretendo, neste texto, explorar as aproximações que Llull estabelece entre a Ordem dos Cavaleiros religiosos, como expressão suprema da unificação prevista por ele de todas as Ordens religiosas militares, e a pregação cristã anti-muçulmana levada a cabo, principalmente, pelas Ordens de pregadores, como os Franciscanos e Dominicanos. O aporte documental será amplo o suficiente para dar conta da proposta que consiste em compreender o projeto luliano dentro da experiência da expansão ocidental europeia, não como algo inédito, excepcional ou diferenciado, mas como expressão de uma postura geral de afirmação da Europa pela defesa da cristandade latina.

\section{Ramon Llull e a pregação cristã}

Quem ler as memórias lulianas registradas na Vita Coetanea, de 1311, perceberá que o despertar religioso de Ramon Llull começou por uma tomada de consciência de que era preciso, por amor a Cristo, "converter para o seu culto e serviço os sarracenos que, em grande multidão, cercam, por todos os lados, os cristãos" (BATLLORI e CALDENTEY, 1948, p. 48). Pela sequência do texto, vê-se que Llull não havia, ainda, abandonado a sua vida pecaminosa; não era o que se poderia chamar um penitente confesso - tais ideias vinham-lhe com insistência à mente e, com elas, o propósito de dar a vida por Cristo. Penitência e abstinência, para ele, pautavam-se por uma firme oposição aos que ele enxergava como inimigos de Cristo e da Virgem Maria. É neste sentido, parece-me, que se pode entender que "converter os sarracenos" era um ato de amor e de devoção. A ambição deste ainda impenitente era, em primeiro lugar, aprender a língua dos infiéis para, num segundo momento, pregar para eles a "verdade da fé católica que está em Cristo". Mais ousado, Llull queria ir ao papa, aos reis, príncipes e demais aristocratas da cristandade para pedir-lhes que construíssem mosteiros onde os religiosos pudessem aprender a língua árabe a fim de pregar a fé aos muçulmanos. 
A confiança que Ramon Llull depositava na pregação como meio eficaz de conversão dos sarracenos pode ser o resultado do que lhe aconteceu quando, em 4 de outubro de 1261, ouviu o bispo de Maiorca que pregava acerca da vida de São Francisco de Assis. Na Vita Coetanea, lê-se que Ramon sentiu-se "provocado pelo exemplo de São Francisco" e que, ouvida a pregação, imitou à letra o que fizera o santo, isto é, vendeu suas posses e separou-se de sua família, não sem antes reservar o suficiente para sua esposa e seus filhos.

No manuscrito ilustrado do Breviculum ex artibus Raimundi Lulli electum4, de Thomas le Myésier, de 1322, no recto do segundo fólio, encontra-se, por toda a página, uma imensa iluminura que ilustra o momento da pregação do bispo. Uma árvore, de tronco e galhos verdes e retorcidos, posicionada no meio do fólio, divide a página em duas cenas. Do lado esquerdo, vê-se o bispo, de capa e mitra, a pregar sobre um púlpito, externo à igreja, dando a entender que fora armado ali para a ocasião. Diante dele, sentado, um bloco compacto e piramidal de ouvintes: dois religiosos, tonsurados e trajando hábitos pretos, estão logo abaixo do púlpito, iniciando o bloco: ambos mantêm os olhos arregalados, mas, um deles, com mão no queixo, demonstra ainda mais atenção às palavras do bispo. Os demais ouvintes, em fileiras, avolumam-se, igualmente atentos. Vê-se Llull, calvo, vestindo um traje vermelho, na segunda ou terceira fileira. Do lado direito da página, ilustra-se o bispo a impor o hábito marrom dos penitentes franciscanos a Ramon, que o veste com a ajuda do prelado, que segura as mangas do burel. A árvore verde, que divide a cena em duas, testemunha o sentido sobrenatural da pregação, posto que uma das copas se dobra e se verte na direção do bispo que prega, à esquerda, e a outra, na direção do bispo que impõe o hábito a Ramon, à direita.

O quadro ajuda-nos a ver e a imaginar a força persuasiva da pregação; é um ato de oratória, não há dúvida, e o Breviculum de Myésier cuida de ilustrar justamente a retórica luliana; mas é também um ato sobrenatural em que, pelo poder

${ }^{4}$ O manuscrito pode ser visualizado no sítio eletrônico da Badische Landesbibliothek Karlsruhe, (LE MYÉSIER, 1322). 
da palavra, Deus pode tocar os corações e mudar-lhes a atitude. Llull conheceu este toque. Tornou-se pregador após ter sido convertido pela pregação. Penso que esse elemento biográfico não pode ser esquecido quando se trata de avaliar o significado histórico de sua prédica, principalmente aquela aos cavaleiros, atores da reconquista, das cruzadas e da expansão da cristandade.

A leitura de conjunto das obras lulianas dedicadas à pregação possibilita relativizar os juízos de especialistas contemporâneos, como Mark Johnston (1996) e Manuel Sánchez (2000), que tendem a minimizar o lugar de Ramon Llull no rol dos pregadores e sermonistas ibéricos. Ambos os autores avaliaram a pregação de Llull prioritariamente pela análise do conteúdo e do impacto histórico de seus sermões, compilados em 1304, sobre outros sermonistas do período; por não notarem que tais sermões foram citados ou evocados em outras coleções, os autores concluíram que os sermões de Llull não trazem nenhuma novidade em comparação com suas demais obras (JOHNSTON, 1996, p. 159) e que não exerceram (quase) nenhuma influência na pregação medieval; Sánchez, por exemplo, chega a dizer que a retórica era irrelevante na compreensão dos sermões de Llull e que a sermonística luliana era uma alternativa, não uma continuação, ao programa predicativo dos frades mendicantes (SÁNCHEZ, 200o, p. 788 e 789). A meu ver, são juízos rigorosos demais e que devem ser relativizados.

Talvez possamos reconsiderar a avaliação de Sánchez, à luz de seu artigo “Todo vale para construir un sermón” (2009), já que, neste texto posterior, o autor circunscreveu o significado do sermão às possibilidades de sua recepção, isto é, ao entorno social dos ouvintes, e não a uma definição retórica apriorística, estabelecida em termos de originalidade textual, como fizera em 2000 (SÁNCHEZ, 2009, p. 247); em outras palavras, o valor de um sermão seria conferido pela sua recepção e poderia ser medido pela sua eficácia religiosa: creio que Sánchez conseguiu alargar os termos da análise e, neste sentido, sua última consideração torna-se bastante útil para este trabalho. 
O ponto de partida aqui assumido é que o estudo da pregação não pode ser dissociado, quando possível, do estudo do sermão e vice-versa. Por pregação, compreendo o pronunciamento oral e performático de um discurso, com base bíblica, moral ou catequética, proferido por um representante eclesial, diante de um público de fiéis ou de pessoas a quem se espera converter (KINZLE, 2000, p. 151). O sermão, por sua vez, teria um sentido mais restritivo de ser o texto estabelecido, antes ou depois da pregação, com finalidade de registro. Tal distinção é tão-somente esquemática e para vias de ilustração, pois, no período de Llull, os termos eram intercambiáveis, permanecendo, no entanto, a distinção entre o oral e o escrito (ALBERTE, 2003; MURPHY, 1983; SERVENTI, 2010). Caso se tomem os sermões lulianos, coligidos em obras tais como o Liber de Praedicatione (1304), Liber predicationis contra Judeos (1305), Sermones de decem praeceptis (1312) ou Sermones de Pater Noster (1312), nem sempre se pode ter ideia do aspecto vivo, oral e performático da pregação de Llull, para cuja dimensão retórica ele dedicou o melhor de seus esforços. Uma avaliação mais vertical deste tema exige a comparação dos sermões escritos com as narrativas lulianas, obras em que o penitente detalhava exemplos de pregação como enunciação discursiva e performance.

A título de exemplo, analisemos dois episódios narrados por Llull, no Romanç d'Evast e Blaquerna (1283)5: o primeiro, no capítulo 66 (De Sancta Maria, ora pro nobis), e o segundo, no capítulo 93 (Quoniam tu solus sanctus). O primeiro episódio põe-nos frente à realidade da pregação, nos tempos de Llull: havia muitos pregadores nas cidades, mas nenhum no campo; uma inteira população de campesinos ficava alijada do ensinamento eclesial por falta de pregadores dispostos a ir para o meio deles. Então, um dos monges da casa em que Blaquerna era, então,

\footnotetext{
${ }^{5}$ O Romanç d'Evast e Blaquerna é uma novela ficcional, de caráter edificante, e com finalidade didática concreta: Llull pretende ensinar e ensinar a ensinar; o fato de o autor redigir a obra em catalão, e não em latim, já denota o que, para ele, é o caminho ascensional rumo ao conhecimento mais alto (a contemplação), que se inicia na língua materna (vulgar) e chega à plenitude com o latim. Por isso, ele inventa um personagem central, Blaquerna, filho de Evast, e descreve toda a sua vida, abordando, com isso, as diversas fases de seu crescimento, até que Blaquerna, após renunciar a sucessão do pai como chefe guerreiro, torna-se eremita, depois abade e, por fim, papa. Além disso, o texto narrativo traz diversas marcas autobiográficas, pois ora Evast, ora Blaquerna se aproximam do perfil de Llull; há também diversos acenos às obras lulianas que são anonimamente evocadas na novela, o que ajuda a criar um sentimento de verossimilhança e realidade. No Livro Derradeiro, Llull afirma que o Livro de Blaquerna, bem como tantos outros de sua autoria, escritos em língua vulgar, são muito úteis para o proveito moral dos milites (LLULL, 2009, p. 70).
} 
abade, decide pedir permissão para dedicar-se a este ofício de pregar às gentes do campo. Antes de autorizar a partida do religioso, o abade Blaquerna dirige-lhe orientações que, a meu ver, podem ser entendidas como um resumo da ars praedicandi de Llull. Enfatizam-se dois modos de pregar: o primeiro modo acontece "por razão", isto é, por raciocínios demonstráveis, e o segundo, "por autoridades", o que dispensa a demonstração (BATLLORI e CALDENTEY, 1948, p. 347).

Em qualquer dos modos, o ouvinte precisa entender o conteúdo da prédica; a inteligência de quem escuta tem de participar do processo de audição, pois, do contrário, ela não poderá anuir à mensagem e, assim, não haverá movimento interno da vontade no sentido de adequar-se à pregação. Blaquerna insiste na explicitação do processo psicológico da prédica: a inteligência capta a mensagem do pregador, transforma-a em memória e, assim, pode voltar a captar outros aspectos desta mensagem. Se o pregador falar em excesso ou se o seu discurso for muito sutil e de difícil compreensão para seu público, a memória dos ouvintes não será capaz de reter as informações e, por isso, a atenção dos ouvintes ficará danificada, causando ignorância e falta de devoção. Por isso, recomenda-se que a pregação seja breve e que seja adaptada ao público: diante de campesinos, gente simples, mas pragmática, prega-se melhor com razões demonstráveis; aos clérigos, ilustrados e letrados, prega-se melhor pela evocação de autoridades e pelo encadeamento lógico de textos.

O segundo episódio, localizado no capítulo 93 (BATLLORI e CALDENTEY, 1948, p. 463), complementa o primeiro; Blaquerna, nesta ocasião, já havia alcançado o sólio pontifício e, como papa, reunia-se com seus cardeais. Um dia, durante o consistório, discutia com eles a respeito de como a fé católica poderia ser exaltada, quando um cardeal entrou na sala logo após ter encerrado uma prédica. O papa Blaquerna, então, dirigiu-se a ele, indagando se vira algum ouvinte a chorar. $\mathrm{O}$ cardeal respondeu que ninguém chorara, mas que muitos dormiram. $\mathrm{O}$ papa ficou consternado. De pronto, argumentou que os sarracenos, gente que vive no erro, tinham pregadores que faziam o público chorar, e estas pessoas eram cheias de devoção durante a prédica. Um dos secretários do papa, oriundo de ultramar, 
afirmara que os pregadores infiéis eram muito devotos e pregavam com fervor; falavam da glória do paraíso e das penas do inferno e, assim, levavam o auditório ao pranto e à contrição.

A conversa prosseguiu e, como acontece em vários trechos do Romance, Llull faz propaganda de suas próprias obras, desta vez, da Arte abreviada de encontrar a verdade e dos Sermões sobre as virtudes e vícios; com base em tais obras, defendese que a pregação, para ser eficaz, precisa de razões naturais (argumentos racionais), devoção (por parte do pregador), consideração (enunciação da glória e da condenação eternas) e brevidade de palavra. A sequência do capítulo leva-nos a entender que tais propósitos são, na verdade, a origem do Liber de Praedicatione, concluído por Llull, em 1304, contendo sermões para cada dia do ano, escritos de modo simples, direto e breve, aptos a serem usados por pregadores que percorreriam as cidades e aldeias.

Ficção e realidade misturam-se na narrativa de Ramon; a pregação, para ele, não é um exercício de originalidade, mas de convencimento em que tanto mais um pregador consegue atingir os espíritos, tanto melhor cumpre o seu papel. Como afirmava Ambrósio Sánchez (2009), tudo vale para construir um sermão, e Llull não desperdiçava as possibilidades que a ocasião lhe oferecia. Por isso, as narrativas são muito úteis para avaliar a aplicação daquilo que, nos textos sermonísticos, vem registrado teoricamente, e, mais importante que isso, em Ramon Llull, a pregação transcende o seu lugar litúrgico e atinge o cerne do ordenamento social. Se, bem entendido, a pregação está circunscrita ao ofício eclesiástico/clerical e é o modo específico de os clérigos agirem, ela dirige-se aos membros deste povo que forma a cristandade e, pelo uso da razão, incide sobre as vontades individuais, a fim de ordenar-lhes segundo um programa de correção moral que favorecerá a estabilidade interna do povo. Por outro lado, a pregação dirige-se também aos infiéis, hereges e cismáticos e, mais uma vez, pela argumentação racional, expõe às inteligências o erro de sua crença e a verdade da fé católica, facultando a sua expansão. $O$ ato de pregar, portanto, solidifica a paz social interna e amplia esta condição aos espaços externos 
com vistas a criar o idêntico, como afirmava o já citado Dominique Iogna-Prat (2016, p. 108).

\section{0 significado político da pregação em Ramon Llull: alguns exemplos}

Por meio do exame de alguns sermões presentes no Liber de Praedicatione (1304) e do Llibre Darrer (1305), pode-se sustentar que, em Llull, a pregação é o modo mais eficaz de a Igreja dilatar sua mensagem pelo mundo e, com isso, congregar um novo povo de Deus, a cristandade; em ambas as obras, o ato de pregar é o primeiro aspecto da natureza militante da cristandade, sendo a guerra contra o infiel o segundo aspecto. Esta recorrente associação, já exposta no Liber de Passagio (1292) e que retomaremos, leva-nos a perceber que a pregação é, a meu juízo, um modo de ação eminentemente político e voltado para o confronto com o outro, seja o cristão dissidente, seja o não cristão.

Nas composições lulianas, a Igreja, como cristandade, aparece, a uma só vez, como herdeira das promessas do Israel bíblico (ideia de povo eleito) e sucessora e continuadora do Império Romano. É o que se verifica, por exemplo, no Sermão para a festa de São Silvestre e Santa Columba (31 de dezembro): “[o bem-aventurado Silvestre] adquiriu o império romano mediante a sua santíssima pregação" (SORIA FLORES, 1963, p. 330). Não nos esqueçamos de que, segundo a tradição, foi o papa Silvestre quem pregou ao imperador Constantino, levando-o a abraçar a fé cristã e que, pelo batismo, o livrou da lepra, doença que lhe incapacitava para o governo ${ }^{6}$.

\footnotetext{
${ }^{6}$ Essa tradição encontra-se bem ilustrada no programa imagético que decora as três paredes do Oratorio di San Silvestre, junto à Basilica dei Santi Quattro Coronati, no monte Celio, em Roma. Este oratório tem planta retangular e foi construído em 1246, às expensas do cardeal Estêvão Normandis. O programa decorativo inclui uma série visiva de 11 cenas de afrescos, distribuídas pelas paredes laterais e na parede de entrada da capela, na altura do teto: tais afrescos retratam a vida de São Silvestre (papa de 314 a 335), incluindo os momentos em que o santo esteve em direto contato com o imperador Constantino; dentre as imagens, destaco a cena do batismo do imperador (coberto por lepra), a cura do imperador pelos méritos do santo e o cortejo que Constantino promove para homenagear Silvestre que monta o cavalo imperial e vem puxado pelo imperador em pessoa. Como se pode notar, estes afrescos expressam a crença romana da donatio Constantini feita a Silvestre por ocasião da mudança da capital para Constantinopla.
} 
No Llibre Darrer, Ramon declara: “a fé cristã começou pela pregação" (LLULL, 2009, p. 40) e, no Sermão para o XXV Domingo de Pentecostes:

A Igreja possui o poder [potestas] de pregar o evangelho pelo mundo inteiro, pois a pregação foi ordenada por nosso Senhor Jesus Cristo. E porque ela assim não faz, é desobediente de um jeito mau; e por consequência, está enferma. (SORIA FLORES, 1963, p. 203).

Quando se trata de pregação, elementos políticos e religiosos escoram-se um no outro. Em Llull, a Igreja confunde-se com a cristandade como dois aspectos de um só mistério e de uma só estrutura histórica. Aquela distinção entre a autoridade (auctoritas) eclesiástica e o poder (potestas) monárquico, instaurada pelo papa Gelásio I (séc. V) e depois incorporada pelo direito canônico ocidental (séc. XII), parece não ter o mesmo significado na obra de Llull, ao menos neste último sermão, na medida em que a pregação aparece como parte de um ato político, marcado pela potestas praedicativa, e não apenas um ato religioso, restrito ao âmbito litúrgicocultual. Deste modo é que se entende como é que a pregação, no princípio, fundou a Igreja-cristandade, depois, conquistou o Império Romano e, mais contemporaneamente, deveria recuperar o Oriente, espaço de infiéis e cismáticos.

No prólogo do Llibre Darrer, Llull, mais uma vez, recorda as motivações que o levaram a percorrer as cúrias prelatícias e as cortes principescas atrás de apoio financeiro para a construção de suas escolas de idiomas com o fito de preparar pregadores para a conversão universal do mundo. Lamentando-se de não haver conseguido encontrar o que buscava, isto é, convencer os líderes cristãos da importância da defesa da fé, o penitente exclama: "A causa de não haver conseguido é que o bem público não tem amigos e, se os tem, são bem poucos, como fica evidente para todos os que querem ver a realidade" (LLULL, 2009, p. 36). No final da mesma obra, após apresentar as espécies de artes que compõem a sua Arte Geral, Llull constrange-se por ver que as ciências lucrativas, que dominam o mundo, impedem que se dê valor às ciências voltadas para a descoberta e a propagação da verdade. 
Nestas artes, Llull enxerga a "utilidade pública" (utilitat pública) e, naqueles que se negam a ajudá-lo, ele percebe os inimigos "do bem público" (bé público) (LLULL, 2009, p. 92). As referências são bem marcadas pela valoração política que contêm: a cristandade, a defesa da fé, a busca pela verdade do conhecimento e, no limite, a pregação, aparecem como categorias políticas já que delimitam os contornos da comunidade cristã por oposição aos muçulmanos e aos gentios. Llull acredita que todo seu esforço de pregador e idealizador de um programa de recuperação dos lugares santos e de conversão universal do mundo é um serviço ao "bem comum e público" [bé comú i públic].

Contrariando uma certa tendência predominante na historiografia, recusome a acreditar que Llull esteja perdido num mar de teocracia dita medieval, em que os elementos da política teriam sido tragados pelas vagas da religião. Ao contrário, a lucidez do autor é tamanha que, na hora de criticar as lideranças ocidentais por sua omissão na luta contra os infiéis, ele apela para termos políticos, já que a finalidade é, sobretudo, política, isto é, tomar de assalto o Oriente muçulmano. Outra razão para o exposto percebe-se no movimento contrário, isto é, quando bens eclesiásticos destinavam-se a finalidades não religiosas, como aparece no já citado Sermão para o XXV Domingo de Pentecostes:

\footnotetext{
Os bens da igreja são constituídos pelas doações dos fiéis. Os fiéis, quando dão esmolas, tocam a túnica do Filho de Deus Pai; e, por este toque metafórico, são curados. Porém, tu, clérigo ou prelado mau, tu não aplicas os bens da igreja para a utilidade pública e comum, pois não dás esmolas aos pobres e aos desvalidos, como é teu dever; tu deixas morrer de fome os membros de nosso Senhor Jesus Cristo e não conservas a igreja contra os infiéis. (SORIA FLORES, 1963, p. 204).
}

Se, antes, o bem comum encontrava, na causa da fé, a sua mais profunda acepção, agora são os bens eclesiásticos, acumulados pelos atos de fé, na forma de doações, que se destinam à utilitas publica et communis. A tais bens comuns, nem mesmo os clérigos podem, impunemente, lançar a mão, pois se destinam, por um lado, a sustentar os membros frágeis (pobres e indigentes) da comunidade e, por outro, a afugentar seus inimigos (os infiéis). 
Não proponho que simplesmente leiamos, em chave política, os fenômenos religiosos, substituindo a tendência que teocratiza o medievo por aquela que o dessacraliza ou laiciza. O que se pretende é evitar o embotamento da nossa imaginação histórica, amiúde influenciada pela mentalidade iluminista, que impede de restituir os conceitos antigos aos seus lugares de origem (SCHWARTZ, 2009, p. 25). A título de exemplo, e porque Ramon Llull contrapõe cristãos a muçulmanos, tracemos um pequeno paralelo entre a concepção luliana, acima exposta, com o uso islâmico dos termos "religião" e "estado/poder político".

A língua árabe conhecia o vocábulo dîn para expressar as obrigações dos crentes para com a Lei (divina na origem, humana na aplicação), como, por exemplo, as orações e as abluções rituais, dando a entender certos aspectos do que nós, ocidentais, costumamos traduzir por religião (AMORETTI, 1998, p. 16); no entanto, como lembra Mohammad Siddiq (2016, p. 82), o termo dîn costumava aparecer combinado com o substantivo dunyâ (o mundo terreno) em inscrições que marcavam a ascensão ao poder de califas e sultões, sobretudo no sul asiático; este costume, de origem mais persa que árabe, tornou-se recorrente a partir do período abássida (750-1250). A expressão al-dunyâ wa'l-dîn (o mundo e a "religião") tornava-se, então, a contraparte de nomes próprios destacados pelo lugar político que seus detentores reivindicavam.

O vocábulo dunyâ, por sua vez, indica o componente mensurável do mundo, a extensão territorial de um poder político que, em árabe, grafa-se dawla. Esta voz, contudo, não é oposta à voz dîn, mas o seu complemento. Percebe-se isso quando se tem presente que dîn manifesta os deveres dos crentes e, sobretudo, dos governantes crentes, dentre os quais, o principal dever é a expansão da Lei corânica, motivo pelo qual não se podia aplicá-lo aos não crentes (SIDDIQ, 2016, p. 82). Em reinos islâmicos com parte da população não muçulmana, a solução foi empregar um termo sem conotação exclusivista, donde o uso de dawla ao lado de dîn. Vê-se, com isso, que o "estado", definido pela voz dawla, não é algo diverso do que se exprime com dîn, visto que, ao fim e ao cabo, ambas as vozes designam, ao mesmo tempo, mas 
não da mesma maneira, aspectos religiosos $\underline{\boldsymbol{e}}$ políticos. Todavia, ainda que se queira entender por dîn, prioritariamente, os atos de oração e de culto islâmico, não se pode ignorar o fato de que, na cultura muçulmana, tais deveres existem em função da edificação da comunidade, que se expressa e se organiza de maneira muito concreta. É surpreendente constatar que, no Islam medieval, a mistura semântica de ambos os vocábulos, ao invés de gerar uma sociedade teocrática, resultou, antes, numa sociedade curiosamente laica (AMORETTI, 1998, p. 15), justamente porque as obrigações para com Deus inscreviam-se nos deveres para com a comunidade.

No caso cristão latino, expresso pela literatura luliana, a situação só muda na medida em que o componente religioso não se esgota em seu senso comunitário/imanente e, por isso, não se deixa cooptar por forças inteiramente políticas, como ocorria no islam. A ênfase na transcendência e na sua irredutibilidade em relação às estruturas políticas constitui, certamente, um fator de distinção entre o mundo latino cristão e aquele árabe muçulmano. Soma-se a isso a presença iniludível do elemento clerical, garante desta transcendência e seu mais abalizado intérprete. Essa específica compreensão obrigava a uma dualidade (religião/política) de todo estranha aos muçulmanos, mas não impedia concretas aproximações. Vê-se isso quando se procede a um levantamento terminológico e semântico das obras lulianas e constata-se que o vocábulo latino religio ou o vernáculo catalão religió possuem exclusivamente o significado de Ordem religiosa (a exemplo das Ordens monásticas, militares e mendicantes) e, ainda, o de estado de vida religioso (relativo aos monges, monjas, frades e freiras). Para expressar, mais ou menos, aquilo que nós denominamos religião, Ramon Llull emprega preferencialmente os termos lex/llei e fides/fe (latim/catalão):

Os infiéis acreditam que fazem o bem quando destroem os cristãos, como se fazia no tempo dos apóstolos; o mesmo se pode dizer dos sarracenos, nos tempos atuais. Estes creem que possuem a verdade e que os cristãos permanecem no erro. Por isso, os religiosos e os prelados inteligentes agem mal quando não pregam a verdade da fé cristã, ensinando-lhes a fé católica cristã que temos e cremos. [...] Conta-se que um certo sarraceno, bem instruído em filosofia, estudou tanto que concluiu que sua lei [lex] era 
falsa; e, então, desejou fazer-se cristão. Ele foi ter com um prelado e disselhe que queria tornar-se cristão. Porém, antes, queria que o prelado lhe expusesse a nossa fé. (SORIA FLORES, 1963, p. 103; 104) - grifos meus.

No Llibre Darrer, a semântica se torna ainda mais nuançada:

Os tártaros e demais pagãos não têm ciência e nem lei. Não têm lei porque não têm pregadores. Não têm ciência porque a inteligência deles capta apenas coisas sensíveis e imagináveis. Por essa razão, a Igreja lhes deveria enviar pregadores para os instruir na santa lei católica com razões probatórias, e que eles [isto é, os pregadores] lhes proporcionassem a ciência do direito, da medicina, da filosofia e da moral, contínua e pontualmente. (LLULL, 2009, p. 58)7 - grifos meus.

O uso da voz lei para indicar um tipo específico de instituição de caráter cultual-religioso ajuda-nos a ultrapassar, um pouco, os mal-entendidos de nossa imaginação histórica, pois, embora o termo se refira a uma manifestação religiosa, ela não se limita a esta única acepção. Sintomático disso é a antiquíssima maneira com que os gregos nomeavam a Bíblia hebraica, ou, ao menos a sua primeira parte, o Pentateuco, com o tou noumou tôn ioudaikôn biblia [os livros da lei dos judeus], como vem grafado na Carta de Aristeias [séc. II a.C.] (COCCIA, 2016, p. 322); se esta formulação não impede de interpretar a "lei judaica" em termos de culto e de religião, pelo menos nos apresenta outra forma de compreender o fenômeno religioso para além de nosso condicionamento situacional, para quem a Bíblia é apenas um livro de religião. Entendida como lei, a "religião" não se torna um campo paralelo ao político e seu concorrente, mas se instaura no cerne mesmo desta realidade social.

Desta forma é que as noções de fé e de lei se circunscrevem naquilo que Ramon Llull chamava de bem comum: pertencer ao Estado cristão (a rigor a cristandade) equivalia a professar uma mesma fé, tutelada pelo corpo clerical e, ao mesmo tempo, obedecer a um princípio normativo comum partilhado pelos mais

${ }^{7}$ Tradução de Eliane Ventorim e Ricardo da Costa. 
diversos níveis legislativos ${ }^{8}$, tutelados por autoridades monárquicas ou republicanas9. Para Llull, a fé e a lei são duas faces de uma mesma moeda: se a primeira compete, em primeiro lugar, aos clérigos, e a segunda, aos príncipes, ambos os agentes são responsáveis por proteger a cristandade inteira, seja pela espada da pregação, seja pela espada dos soldados: nos trechos citados há pouco, vimos que Llull dota os pregadores de um papel de ensino religioso (para combater os erros dos sarracenos), mas também de ensino científico (para combater a ignorância dos tártaros). Nos dois casos, os pregadores são forças complementares ao exército cristão, a cavalaria, que jamais é dissociada desta missão político-religiosa.

\section{A pregação e a Ordem dos Cavaleiros religiosos}

É bem verdade que Ramon Llull, desde cedo em sua carreira, se preocupou em compor um repertório ascético que preparasse os cavaleiros cristãos para aquilo que ele considerava ser a missão fundamental da cavalaria na cristandade, como podemos encontrar, por exemplo, no Livro da Ordem da Cavalaria [Llibre del Orde de Cavalleria], de 1275. Neste tratado literário, observa-se que Llull confere à cavalaria laica uma função, se não inteiramente eclesial, ao menos atrelada a ela, pois os cavaleiros são os defensores e multiplicadores da santa fé católica (BATLLORI e CALDENTEY, 1948, p. 112); este entendimento destoa significativamente do que rezava a legislação régia afonsina, presente, por exemplo, na Segunda Partida, Título XXI [De los caballeros et de las cosas que les conviene de facer], de Las Siete Partidas, que torna os cavaleiros os grandes defensores dos territórios do reino, e não funcionários da Igreja.

\footnotetext{
${ }^{8}$ Refiro-me, sobretudo, à distinção entre lex (a lei escrita de base romana) e consuetudo (a lei "oral" de base germânica) e a toda a diversidade jurídica e legislativa que podia manifestar-se nos mais diferentes espaços do Ocidente latino, uma vez que, como lembra Paolo Grossi (2007), o medievo não conheceu um Direito (no sentido conferido pela Modernidade "estatalista"), mas uma ordem jurídica construída pelas mediações entre governos e sociedade.

${ }^{9} \mathrm{Se}$, quanto ao direito, o ponto de vista assumido é aquele de Grossi, há que se ter presente que o medievo latino conheceu inúmeras manifestações jurídicas, nem sempre assimiláveis a territórios que tendemos a chamar de Estados (reinos, principados, impérios, cidadesestado, etc.). Sendo assim, não só as monarquias, em suas múltiplas formas, mas também as comunas (ou repúblicas) e demais associações sociais eram autorizadas a tutelar as normas e os canais de mediação de conflito (cf. Reynolds, 2006).
} 
Porém, como dito, o que está em jogo aqui não é a cavalaria como ordem social, mas como uma das formas institucionais de vida religiosa consagrada da Igreja latina, conhecida como Ordem militar ${ }^{10}$, que englobava diversas expressões, como a Ordem do Hospital (1048), do Templo (1118), dos Teutônicos (1190), de Calatrava (1158), de Uclés (1174), entre outras. Ramon Llull, que redigiu seus tratados entre o final do século XIII e começo do XIV, conhecia a história bissecular destas Ordens de cavalaria e, frente ao seu projeto de reconquista da Terra Santa e de conversão geral do islam à fé romana, propunha que o papado procedesse a uma reforma geral destas ordens, unificando-as numa só instituição custeada pelo dízimo eclesiástico e diretamente submetida ao controle papal através de um cardeal especialmente designado para fazê-lo (LLULL, 2009, p. 64).

No projeto luliano, nem sempre é fácil dissociar a cavalaria secular, descrita no Llibre del Orde de Cavalleria, das Ordens religiosas militares, conforme veremos no Liber de Passagio (1292) e no Llibre Darrer (1305). Por exemplo, no Livre de Contemplació en Deu (1276), escrito em árabe e, depois, traduzido em catalão, Llull opõe os cavallers celestials, isto é, aqueles que obedecem à natureza política, religiosa e eclesial da cavalaria, aos cavallers mundans ou cavallers seguons lo mon [cavaleiros que vivem segundo o mundo ou segundo os pressupostos do poder e do interesse próprio] (FERRA, 1910, p. 58). No mesmo capítulo em que se refere aos cavaleiros celestiais, mencionam-se também los sants cavallers religioses (FERRA, 1910, p. 59): quem seriam exatamente estes últimos? Os mesmos cavaleiros celestiais? Ou os membros das Ordens militares, cuja existência se justificava na perspectiva da libertação da Terra Santa?

\footnotetext{
${ }^{10}$ Tradicionalmente, os historiadores assumem que as Ordens militares são instituições híbridas, isto é, monásticas e cavaleirescas ao mesmo tempo, o que não é um erro, mas esconde sérias imprecisões. Em primeiro lugar, é preciso ter presente que, de acordo com normas canônicas, era vetado ao monge o porte de armas, o que impossibilitaria a existência de uma ordem "monástica" de cavalaria; em segundo lugar, a diversidade dos institutos de vida consagrada na Baixa Idade Média concebia a existência de cavaleiros religiosos que não precisariam importar costumes monásticos para expressar o próprio carisma e devoção. Assim, o que distingue uma ordem militar de outras ordens religiosas é, sobretudo, a possibilidade de portar armas e de engajar-se em lutas, desde que pela defesa da fé, proteção das fronteiras da cristandade, recuperação da Terra Santa, proteção dos peregrinos, pobres e clérigos, dentre outros. Neste sentido, acompanho a proposta de Sam Conedera de definir os cavaleiros religiosos de "Cavaleiros Eclesiásticos" e não "monges guerreiros", como se costuma (CONEDERA, 2015, p. 10).
} 
O Livre de Contemplació não oferece resposta conclusiva, mas permite injunções: em primeiro lugar, relaciona estes cavaleiros religiosos à recuperação da Terra Santa, o que os aproximaria das Ordens militares; em segundo lugar, os intitula 'religiosos', adjetivo que, como vimos, se aplica aos institutos de vida consagrada; em terceiro lugar e, aqui, mais importante, os associa à pregação, ou melhor, os considera também como pregadores: "Senhor, que os santos cavaleiros religiosos ... preguem a verdade da vossa paixão aos infiéis...” (FERRA, 1910, p. 59). Neste momento, interessa menos a real resposta de Llull a esta dúvida do que perceber que ele, ao longo do texto, insiste na alta condição do ofício da cavalaria: "os cavaleiros foram postos no mundo para que o mundo encontrasse a paz" (FERRA, 1910, p. 60); "bem-aventurados aqueles cavaleiros que mantêm a ordem da cavalaria segundo a nobreza do ofício da cavalaria", pois "os cavaleiros são o motivo por que os príncipes detêm a terra; os cavaleiros, Senhor, são o motivo por que os príncipes mantêm a justiça; pelos cavaleiros, os homens maus são vencidos e punidos e, pelos cavaleiros, a santa Igreja é sustentada" (FERRA, 1910, p. 62). No Livre de Contemplació, as funções cavaleirescas não são inteiramente divididas entre as duas milícias, pois ambas estão ao serviço de uma única causa. Todavia, nas obras redigidas após 1291, Ramon Llull insere uma distinção entre elas, decorrente, com alguma segurança, de seu atual ceticismo para com as boas intenções da cavalaria secular.

Assim, no Liber de Passagio (1292), dedicado ao papa Nicolau IV, Llull recomenda que o pontífice reduza a uma única Ordem os Hospitalários, Templários, Teutônicos, os irmãos de Uclés e de Calatrava, cujo nome passaria a ser Ordem do Espírito Santo (Ordo de Spiritu Sancto) (GARI e REBOIRAS, 2003, p. 328), substituído, depois, por Ordem da Milícia [Orde de la Milícia], no Llibre Darrer (LLULL, 2009, p. 62), em que também se lê Ordem do guerreiro [Orde del guerrer] (LLULL, 2009, p. 70). Malgrado o fato de que esta ordem fosse um projeto proposto e defendido por Llull em, pelo menos, quatro de suas obras, e que tal projeto nunca tenha sido efetivamente implementado, a estruturação da nova instituição seguia muito de perto o que já era praticado pelas ordens militares acima mencionadas. 
A Ordem do Espírito Santo ou Ordem da Milícia seria um instituto religioso no sentido canônico do termo, pois seus membros deveriam ser celibatários, usar hábito - descrito minuciosamente por Llull -, emitir votos religiosos, possuir regra e viver em comunidade. Como uma ordem de religiosos leigos, os irmãos seriam assistidos por clérigos ordenados adscritos à comunidade que ministrariam os sacramentos e a formação. O propósito luliano era aperfeiçoar, na nova ordem, os defeitos das antigas e, principalmente, torná-la mais eficiente para a conquista da Terra Santa e para a missão; como ordem militar, seus religiosos deveriam equilibrar os deveres de soldados na guerra e os deveres de religiosos na vida comunitária, conforme definia o bispo cruzado de São João de Acre (Palestina), Jacques de Vitry (1180-1240), no Sermão 37, ad Fratres ordinis militaris (PITRA, 1888, p. 406).

Estes religiosos da milícia de Jesus Cristo articulam-se com os religiosos pregadores como duas faces de uma única medalha, a ecclesia militans ${ }^{11}$, como vem definida a cristandade no Sermão para o XXV Domingo após Pentecostes (SORIA FLORES, 1963, p. 202). No Llibre Darrer, a conquista discursiva, operacionalizada pelos pregadores, antecede a conquista militar, a cargo dos soldados religiosos.

A conquista discursiva é da responsabilidade de um destacamento igualmente militante, mas não militar, composto de pregadores, isto é, clérigos intelectualmente bem formados nas escolas de teologia e de línguas orientais que, no projeto luliano, deveriam ser preparatórias para a missão além-mar. A estes religiosos, Llull vincula dois tipos de empreendimentos racionais dependentes de sua Arte Geral de expor a verdade: a pregação e a disputa. Por pregação entende-se a exposição exegética e hermenêutica das Escrituras cristãs segundo os pressupostos e normas da homilética litúrgica. A disputa refere-se ao debate argumentativo e retórico com os sábios ou doutores das comunidades religiosas a que se dirigem os pregadores: no Llibre

\footnotetext{
${ }^{11}$ É bem verdade que, num sentido mais amplo, igreja militante pode se referir ao estado peregrino da Igreja neste mundo, para distinguila de seu estado glorioso (ecclesia thiumphans) e do estado padecente (ecclesia poenitens), como vem exposto, sobretudo, no painel dito "Il trionfo dei Domenicani", da Sala do Capítulo do Convento de Santa Maria Novella, de Florença, conhecido como Cappellone degli Spagnoli (obra de Andrea de Bonaiuti, séc. XIV). Este programa de afrescos ilustra bem como os pregadores dominicanos entendiam o papel da pregação na edificação militante da Igreja, tendo em vista sua ascensão à glória celeste.
} 
Darrer, os muçulmanos e os judeus são denominados de infiéis; os cristãos de rito bizantino (gregos), os jacobitas (monofisitas de língua siríaca) e os nestorianos (assírios orientais de língua caldeia) são classificados como cismáticos; os tártaros e outros gentios que não haviam, ainda, aderido a nenhum dos credos decorrentes do monoteísmo abraâmico, são chamados de pagãos (LLULL, 2009, p. 38-63) ${ }^{12}$.

A segunda conquista é bélica, conduzida por uma guerra bem preparada e executada pelos católicos contra todos os infiéis, marcadamente os sarracenos. O objetivo é evitar todos os erros que os latinos cometeram, desde o século XII, quando conquistaram importantes postos no Oriente, os quais foram perdidos em 1291, com a tomada muçulmana de Acre. Ramon Llull, ao lado de outros tantos estrategistas cristãos, procurava analisar o fracasso das missões anteriores e encontrar novas maneiras de, definitivamente, conquistar o Oriente (LLULL, 2009, p. 63-80). São ideias que ele, depois, apresentou ao papa, cardeais, reis e príncipes e que foram, de certa forma, discutidas no Concílio de Vienna, em 1311.

O confronto armado sustentado pela Ordem do Espírito Santo, como exposto no Liber de Passagium, seria presidido por um almirante que, como "senhor do mar" [dominus maris], governaria a armada cristã com a finalidade de fechar o Mediterrâneo aos navios não cristãos, manter a guarda da costa sírio-palestina e atacar e vencer o sultão do Egito e seus mamelucos que impediam a conquista da Terra Santa. No Llibre Darrer, Llull substitui o almirante por um Mestre Senhor Rei Guerreiro [Magister Dominus Bellator Rex], isto é, um rei propriamente dito que, ao abraçar a vida religiosa militar, deveria ser solteiro ou desimpedido dos compromissos matrimoniais para dirigir a santa ordem da cavalaria aos seus fins últimos, isto é, manter a guerra permanente contra os reinos islâmicos e assegurar a pregação cristã aos infiéis, com a finalidade de convertê-los. A superioridade cristã, no mar, deveria ser seguida por uma efetiva vitória também em terra e, por isso, a Ordem da Milícia precisava ser um reino propriamente dito, pois os inimigos da cruz

\footnotetext{
${ }^{12}$ Esta conquista argumentativa, também descrita no Livre de Contemplació, visa reproduzir, pela mimesis, o processo predicativo de Cristo e dos Apóstolos, cuja pregação conquistou a Terra Santa pela palavra e sem o uso de armas (FERRA, 1910, p. 58).
} 
se organizavam igualmente em estados políticos. No Liber Acquisitione Terrae Sanctae (1309), enviado ao papa Clemente V, Llull não menciona mais o bellator rex, cuja autoridade sobre os milites religiosi seria exercida por um mestre geral escolhido dentre os próprios irmãos de hábito. O motivo alegado para a substituição é a impossibilidade de se garantir que o rei guerreiro e seus sucessores mantivessem íntegra a finalidade da Ordem, donde se deduz certa desconfiança de Llull pelo modo de agir dos monarcas cristãos.

Em suma, a Ordem da Milícia e os pregadores adscritos a ela integram uma ação conjunta de razão e coerção que deveria consolidar a superioridade latina e católica no Oriente, em primeiro lugar, pela submissão à Igreja romana de todos os cristãos considerados cismáticos; em segundo lugar, pela conversão cristã dos tártaros pagãos antes que se tornassem muçulmanos - Llull não consegue disfarçar a convicção de que o monoteísmo, qualquer que seja, é mais inteligente e, por isso, mais atrativo do que toda expressão religiosa politeísta; em terceiro lugar, pela instrução correta dos doutores muçulmanos acerca da teologia cristã, pois Llull pensava que os muçulmanos não se convertiam devido a uma ideia distorcida que faziam do cristianismo ${ }^{13}$ : ora, isso nos permite notar que a conversão seria consequência do conhecimento racional e de operações lógicas, o que denuncia o extremo apego luliano ao método científico de exposição da verdade e que, ao mesmo tempo, o levava a desconsiderar o componente cultural e identitário que envolve as práticas religiosas.

\section{A pregação e a guerra da cristandade contra o islam}

No repertório conceitual de Ramon Llull, conquista e missão compõem um único procedimento eclesial para com comunidades não latinas e não cristãs. Nisso, o pregador mostrava-se ligado, por exemplo, à perspectiva pontifícia que, entre os séculos XI e XIII procurou estender os tentáculos da Igreja romana para além do

${ }^{13}$ Ramon Llull expõe este problema no Sermo de Dominica infra octavas Ascensionis (SORIA FLORES, 1963, p. 103-106). 
continente europeu, sobretudo para o Norte de África e para o leste bizantino (VONES, 2000, p. 205). O fortalecimento naval cristão no Mediterrâneo ocidental, a superioridade mercantil de cidades italianas muito ligadas à autoridade papal, a ideologia da cruzada que sustentava a afirmação de reinos ibéricos e meridionais, a teoria missionária elaborada pelas Ordens mendicantes que traziam novas ideias para a propagação da fé, tudo isso aliava-se às guerras internas nos reinos islâmicos, africanos e ibéricos, tornando vulneráveis os potentados muçulmanos e abrindo aos cristãos latinos novas perspectivas de missão em suas terras.

Ramon Llull, em 1297, reforçou esta ideologia missionária no poema a que deu o sugestivo título de Desconhort (o Desconsolo), pois nele o penitente se lamenta dos esforços que envidou e do pouco que conseguiu:

\author{
Quando pus-me a considerar do mundo o provimento \\ Como poucos são cristãos e muitos os incréus \\ Então tomei coragem e com tal pensamento \\ Acorri aos prelados e aos reis igualmente, \\ aos religiosos fui mostrar qual o procedimento \\ P'ra se fazer uma cruzada e uma grande pregação \\ Que com ferro e força e com bons argumentos \\ Se desse à nossa fé um tão grande crescimento \\ Para assim os infiéis conhecerem conversão \\ (BATLLORI e CALDENTEY, 1948, p. 1096).
}

A uma fé que cresce por argumentos e por coação, Llull associa a teoria das duas espadas (Lc 22,38), interpretada por ele a partir da combinação de pregação e de guerra santa ${ }^{14}$. Na segunda distinção do Llivre Darrer, que trata da guerra contra o infiel, a pregação e os pregadores aparecem no capítulo sexto, como parte das estratégias da conquista militar ${ }^{15}$. O motivo é, ao mesmo tempo, espiritual e

\footnotetext{
14 “Já disseram os apóstolos a Jesus Cristo: 'Aqui temos duas espadas' (Lc 22, 38). Ele respondeu: 'É suficiente'. Com isso deu a entender que tínhamos de guerrear com a pregação e com as armas contra os homens infiéis" (Llibre Darrer, LLULL, 2009, p. 41) - tradução de Eliane Ventorim e Ricardo da Costa.

${ }^{15}$ A primeira estratégia, como vimos, é fundar uma Ordem da Milícia na forma de um reino cristão regido por um rei guerreiro eleito; a segunda, é organizar esta milícia na forma das Ordens militares; a terceira, é saber que, para conquistar o Oriente, o melhor caminho é começar pela conquista da Península Ibérica (reino de Granada e Andaluzia) e seguir pelo norte de África, por terra, até chegar ao Egito; a quarta, é aproveitar todas as vantagens que os latinos têm em comparação aos muçulmanos (contingente, tecnologia, tática, superioridade naval, logística, etc.); a quinta, é a força da armada latina sem comparação com a muçulmana (Llull está convencido de que os latinos, naquele momento, são mais ricos e mais bem equipados do que os sarracenos; para ele, o mar Mediterrâneo, principalmente na sua parte ocidental, voltara a ser um mar cristão e, sobretudo, latino).
} 
pragmático. Espiritual, pois Llull nunca perde de vista o fato de que propõe uma guerra em nome de Jesus Cristo e da igreja militante ["pro nomine Iesu Christi et pro ecclesia militante” (Soria Flores, 1963, p. 203)], uma guerra que tem como finalidade a conversão, não a destruição dos infiéis ${ }^{16}$. Pragmático, porque a pregação é também útil no campo de batalha, seja para suster o moral dos guerreiros e fortalecer sua fé, seja para instaurar o discurso vencedor tão logo a conquista aconteça.

Pregação e guerra retornam no Sermão para o XXV Domingo após Pentecostes (Soria Flores, 1963, p. 202-206). Neste discurso, Ramon Llull analisa a perícope evangélica "Se eu tocar ainda que só a fímbria de seu manto, ficarei curada" (Mt 9, 21), que se refere ao gesto de uma mulher que sofria de hemorragia menstrual e que tocou o manto de Cristo no meio da multidão. A cena bíblica é repartida em três elementos ${ }^{17}$ : mulher enferma, manto e toque, e cada um destes elementos recebe um sentido alegórico: pela mulher hemorrágica, interpreta-se a igreja militante (ecclesia militans) ou a congregação de todos os fiéis; o manto de Cristo significa a sua natureza humana (ou encarnação); o toque curativo equivale aos modos com que a mulher-igreja pode tocar este corpo, isto é, pela oração, pela pregação e pela recuperação da Terra Santa. Estes modos são relacionados, no sermão, a sujeitos eclesiais diferentes: para a oração, os fideles amatores (os fiéis amantes, isto é, os leigos); para a pregação, os clérigos; para a recuperação da Terra Santa, os cavaleiros. A congregação de todos os fiéis empenha-se inteiramente no toque curativo, porém, cada ordem age de acordo com sua vocação e ministério.

Faço notar o jogo de sinédoque presente no sermão: o corpo humano e carnal de Cristo, extensível no tempo e no espaço, equipara-se à terra em que nasceu, viveu

\footnotetext{
${ }^{16}$ No Liber de Passagio [Tractatus de modo convertendi infideles], encontramos a seguinte afirmação: "O princípio que começa pela concordância é mais forte do que aquele que começa pela contrariedade, mas iniciar o debate com os infiéis para se chegar à concordância sobre as dignidades de Deus e as razões necessárias importa mais do que guerrear contra eles, contrariando-os com a espada corporal e confiscando as terras que possuem e até mesmo matando-os" (GARì e REBOIRAS, 2003, p. 349).

${ }^{17} \mathrm{O}$ sermo modernus (também chamado de método escolástico) é a base estilística e metodológica desta peça sermonária luliana; ele consiste em dividir as matérias (prothema e thema), intepretá-las a partir de sutilezas exegéticas que conduzem, por fim, ao esclarecimento do texto bíblico e à sua atualização comunitária. Para mais informações, cf. ALBERTE, 2003, p. 65.
} 
e morreu. A transposição do sentido de corpo real a corpo místico de Cristo - a Igreja - já havia sido feita desde as origens cristãs, como atestam as epístolas paulinas. Porém, o que Llull opera, agora, sem dúvida motivado por acontecimentos e autores mais contemporâneos a si, é um processo contrário de territorialização do corpo místico que irá exigir que a igreja militante, subsumida na cristandade latina, não renuncie ao terreno primário de sua sacralidade, isto é, os reais e históricos locais da passagem de Cristo pelo mundo (IOGNA-PRAT, 2016, p. 130-131). Toda a teologia, liturgia, cultura e historiografia das cruzadas, produzidas desde 1095, de algum modo, refluem nesta centralidade salvacionista que Llull confere à terra que acredita santa (TYERMAN, 2010, p. 203-204). Ela é mediadora da cura porque materializa e historiciza o antídoto da doença, a encarnação de Cristo. A espiritualidade das cruzadas, que de resto se tornou comum a clérigos, aristocratas, citadinos e camponeses, operacionalizava esta passagem do particular (o corpo de Cristo) para o geral (a terra de Cristo) e, mais do que isso, elevava esta terra à qualidade de sacramento, donde deriva a sua capacidade de perdoar pecados, de unir a Deus, de suscitar novos mártires e de aproximar o reino dos céus ao reino dos homens.

Entende-se, assim, porque a conquista muçulmana da Terra Santa suscitava tanto transtorno na mente dos latinos ocidentais. Perdiam eles um sacramento, mas também a figura de sua verdadeira pátria, bem como a capital de seu império. A terra de Cristo, por direito, deveria pertencer aos discípulos de Cristo e não à caterva dos infiéis, oriundos do erro e da fraude ${ }^{18}$. Ramon Llull não poupa os muçulmanos; a Terra Santa não é deles e, portanto, sua conquista (ou reconquista) era um ato de justiça' ${ }^{19}$, conclusão também aplicada ao caso ibérico (JOSSERAND, 2002, p. 79).

\footnotetext{
${ }^{18}$ Tratando da conversão dos infiéis, Ramon Llull coloca a luta pela fé como um ato de justiça em vista da recuperação do território tomado pelo islam e que antes pertencia à Igreja (Llull usa a expressão "terras da igreja"). Estas terras parecem incluir o Oriente, mas também a África e os territórios europeus. Ver Tractatus de modo convertendi infideles (GARÌ e REBOIRAS, 2003, p. 345).

${ }^{19}$ A mesma ideia é reafirmada no Llibre Darrer, a Terra Santa e os territórios ocupados pelos infiéis são terras arrancadas aos cristãos, portanto, passíveis de serem reivindicadas justamente (LLULL, 2009, p. 63).
} 
Entre os estudiosos de Ramon Llull, há muita divergência sobre o significado de sua real posição acerca da guerra santa e da cruzada ${ }^{20}$. Há quem procure justificar que o pregador maiorquino, no fundo, era um pacifista que não aceitava a prática da violência em nome da religião (JAULENT, 2013, p. 26; MERINO, 1993, p. 269); há quem, ao contrário, percebe um endurecimento de sua posição antiissâmica, para a qual a guerra seria não só inevitável, mas necessária, porém, subordinam a violência religiosa aos seus intentos missionários que supõem sempre o diálogo (GARÌ e DOMÍNGUEZ, 2003, p. 304). Deste ponto de vista, Llull teria defendido a guerra santa como forma de obrigar os cismáticos e infiéis a ouvirem os sermões dos pregadores latinos (ENSENYAT, 2008, p. 355), razão pacífica que lhe retira a responsabilidade pela violência cruzada contra os membros de outras comunidades de fé.

Não pretendo tomar partido neste debate que, de resto, me parece centrado em motivos alheios ao deste texto; ressalto apenas que, entre 1292 e 1311, a vasta obra luliana dedicada à conversão do infiel e à recuperação da Terra Santa apresenta, sim, mudanças de perspectiva, mas o juízo historiográfico acerca desta mudança, no geral, apresenta-se orientado, mais uma vez, pela divergência de opinião que, de um lado, vê Llull como um homem avançado para seu tempo e, de outro, como um típico 'homem medieval', seja lá o que isso signifique.

\footnotetext{
${ }^{20}$ Neste texto, não seria cabível uma larga conceituação de 'guerra santa' e 'cruzada', dadas as grandes proporções deste debate na historiografia. Ressalto, no entanto, que o termo 'cruzada' não era empregado até, pelo menos, o século XIV; em seu lugar, preferiam-se termos mais genéricos, como passagium (passagem), peregrinatio, iter (caminho), recuperatio Terrae Sanctae (Llull, nas obras escritas em catalão, emprega também passatge que traduz inteiramente a ideia de passagium). Como se pode ver, a experiência social inaugurada, de certa forma, pelo papa Urbano II, em 1095, acentua a noção de marcha para o Oriente, com a finalidade de libertação dos lugares santos da fé cristã e sua anexação à cristandade latina, o que supõe uma ação militar e política, pois a Palestina havia sido incorporada ao império islâmico desde o século VII. Em contrapartida, e dado que nunca houve uma declaração legislativa ou jurisprudencial que definisse os fundamentos desta empreitada ocidental, o gesto de ir ao Oriente não pode ser visto apenas como ação militar, muito embora a simples noção de peregrinação não dê conta de suas diversas motivações, muitas delas penitenciais e estritamente religiosas. Seguindo este raciocínio, considero que o conceito de 'guerra santa', muito mais antigo e operacionalizado, desde, pelo menos, a época carolíngia, possa expressar os sentimentos envolvidos neste processo, pois compatível com a característica agonística das comunidades cristãs latinas (em sentido exotérico e esotérico) e com a situação do Ocidente, nos séculos XI-XIII: guerra santa, neste caso, mantém-se como conceito aberto e flexível que se traduz por qualquer posição tomada a partir da conviç̧ão de que se age publicamente em nome da fé (com ou sem aval institucional ou eclesiástico) com o fito de se corrigir os erros e instaurar a verdade: pode, portanto, ser usado para indicar a luta contra o islam, os hereges, os cismáticos, os pagãos e contra todos os demais que o poder político considerar uma ameaça à sua própria autoridade. Para maiores discussões, remeto o leitor para as seguintes obras: RUBENSTEIN (2011), TYERMAN (2007; 2010), GARÌ e DOMÍNGUEZ (2003, p. 258-262), FLORI (2013).
} 
Consoante ao que sustentei sobre a cristandade militante, a partir da própria obra luliana, não consigo dissociar sua ação de escritor, teólogo, filósofo e apologista de um explícito engajamento no ideal cristão latino da guerra santa, ideal este que não era uma exceção ou exclusividade de alguns indivíduos menos doutos ou menos santos, mas que se encontrava presente em autores eclesiásticos e seculares, desde os tempos carolíngios (DELARUELLE, 1941) até, pelo menos, o século XVI. O apreço pela guerra santa tendeu a aumentar, desde o século XII, por meio de diversos suportes, como os sermões, as vidas de santos, a liturgia, a arte sacra e profana, como as canções de gesta, cujo sucesso nos meios aristocráticos laicos é bastante conhecido (BARTHÉLEMY, 2010, p. 462). É bem provável que este sucesso deveu-se à capacidade de traduzir, em linguagem épica, as ações guerreiras de uma nova elite cavaleiresca que, para afirmar sua posição, evocava para si o passado francocarolíngio e, sobretudo, o fundamento bíblico e cristão das sociedades ocidentais latinas. Em outras palavras, as canções de gesta são expressões poéticas que elevavam ao patamar de defensores da cristandade aqueles cavaleiros que, localmente considerados, podiam não passar de senhores orgulhosos e um tanto tirânicos.

Dito de outro modo, as lideranças latinas - como as aristocracias condais, casas monásticas, as comunas italianas e até o papado - aproveitaram-se do clima de medo provocado por eventuais incursões islâmicas ${ }^{21}$ e do fato de serem vistas como defensoras do espaço cristão para fins próprios, entre outras coisas, para estenderem ainda mais a sua autoridade e controle no interno da cristandade. O tema antiislâmico, neste caso, atrela-se à intervenção de certas instituições e atores políticos num contexto de crise. Tendo por inimigo comum o elemento muçulmano, comunidades eclesiásticas e aristocráticas passam a compartilhar também um mesmo discurso em que os assassinatos de cristãos por muçulmanos tornam-se

\footnotetext{
${ }^{21}$ Fontes árabes (Ibn Khaldun e al-Athir) confirmam que o emir de Mahdia, Tamīn ibn al-Mu'izz, comandava uma rede de pirataria em cidades italianas. A dinastia zírida, à qual pertencia Tamīn, possuía autoridade sobre a Sicília, interrompida pela chegada de forças normandas, em 1075; deste ponto de vista, as investidas islâmicas, longe de serem uma ação de conquista da cristandade, era uma ação de retaliação ou de retomada da autoridade perdida (cf. KING, 2015).
} 
sacrifícios martiriais, cuja força sobrenatural e significado heroico se transferem para os que defendem o espaço cristão, sejam os cavaleiros, monges ou papas.

O discurso antiislâmico, portanto, desempenha uma função ordenadora da própria identidade da cristandade latina, que evoca para si toda a força política e religiosa do messianismo apocalíptico. Para tornar-se prática, esse discurso assentou-se em experiências sociais concretas: liturgias, devoções, confrarias leigas, ordens militares, festas cívicas, sermões, pactos políticos, assembleias, renegociação de dívidas, reordenamento jurídico, procissões, romances, poemas e gestas. Costumamos pensar as cruzadas como deslocamentos militares intercontinentais e como embates entre exércitos, mas as cruzadas eram muito mais do que isso, eram movimentos sociais que abarcavam as comunidades latinas inteiras e comprometiam as intenções morais e espirituais de quase todos os indivíduos que compunham o território cristão; por detrás das cruzadas havia uma espiritualidade especificamente ocidental, militante e expansiva que, como defende Christopher Tyerman (2010, p. 56), correspondia plenamente à demanda de uma sociedade guerreira. Em outras palavras, e para citar novamente a Tyerman, não é a cruzada que tornou a Europa um lugar violento, mas a violência institucionalizada nas sociedades guerreiras europeias é que inventou a cruzada (TYERMAN, 2007, p. 134).

Para este autor, o discurso antiislâmico e a própria instituição da cruzada decorrem de sua articulação com o social, isto é, são produtos de relações políticas consolidadas ou que pretendem se consolidar e, como tal, são formas específicas de se participar do jogo do poder num lugar e num tempo precisos. Este dado é digno de nota, pois a historiografia das cruzadas e da violência contra as minorias costuma professar uma conceituação apriorística para a violência e a intolerância, destituindo-as de base temporal que as explique ${ }^{22}$. No entender de Tyerman (2007)

\footnotetext{
${ }^{22}$ Bastante elucidativa desta forma de conceber a violência e a intolerância é a obra de Norman Cohn, A Conspiração mundial dos Judeus: Mito ou Realidade [edição brasileira de 1969]. No primeiro capítulo (Origens do Mito), Cohn advoga raízes tardo-antigas para as representações monstruosas e demoníacas dos judeus pelos cristãos, representações duradouras, alojadas no âmago das comunidades cristãs e que "foram revividas e integradas numa demonologia inteiramente nova" a partir do século XII (COHN, 1969, p. 25-26). Estas imagens (ou fantasias, como chama o autor) distorcidas sobre os judeus, invenção de padres, ficavam à disposição de uma vontade coletiva popular que as ativava e atualizava em momentos específicos.
} 
e Nirenberg (2001), a intolerância contra as minorias e a operação da cruzada não são indicativos de uma violência perene encubada nalgum lugar social oculto (Cohn diria "crenças coletivas") e que, de vez em quando, se materializaria e manifestaria sua inexorável continuidade. De modo diverso, Nirenberg sustenta que os discursos e práticas associados à violência contra grupos tidos por minoritários "adquiriam vigor unicamente quando as pessoas decidiam que era relevante e útil e, que esta decisão reestruturava o discurso. Em suma, o discurso e a ação adquirem unicamente significado relacionando-se entre si” (NIRENBERG, 2001, p. 15).

O pressuposto de Ramon Llull orienta-se pela conquista espiritual, cuja finalidade é a conversão dos cismáticos, pagãos e infiéis e a entrada deles na Igreja romana; todavia, a consecução deste supremo objetivo dependia de diversos instrumentos: pregadores, reis, papas, cavaleiros, escolas, livros, navios, mercadores, cidades, mercenários, intérpretes etc. Tais elementos existiam há séculos na sociedade cristã latina, mas a finalidade suprema da missão conferia-lhes um outro sentido, os arregimentava num quadro social coeso, orgânico e em relação, dito de outro modo, reestruturava as hierarquias, reorganizava as práticas políticas, os métodos pastorais, os sistemas de arrecadação e distribuição de dinheiro e até mesmo influenciava os currículos dos centros de estudo. Avaliar esses processos na perspectiva da cruzada ou da missão não as torna menos violentas, porém ajuda a não julgarmos o passado por princípios que não eram os dele e a compreendermos melhor os limites da própria violência.

\section{Conclusão}

No Tractatus de modo convertendi infideles (1292), Ramon Llull oferece ao papa e ao colégio cardinalício seis maneiras de se levar os muçulmanos a se tornarem cristãos. Seus argumentos começam pelas táticas de guerra por mar e por terra e, depois, pelas modalidades de interação com a população dos infiéis (debates, pregação, fundação de escolas e distribuição de livros). Diferentemente de alguns contemporâneos seus, também engajados no enfrentamento do islam, como 
Fidenzio de Pádua, William Durant, William Adam ou mesmo Salimbene de Parma, Llull parece ser o último a acreditar que a cruzada, isto é, a luta armada contra os não cristãos, podia ajudar a expansão da fé (LEOPOLD, 1998, p. 141).

Valeria a pena examinar como um homem tão consciente da situação histórico-social de seu tempo podia insistir num tópico já desacreditado, inclusive, pelos papas e cardeais, que muito ganhariam com a vitória cristã. Frades como Salimbene e Fidenzio não negavam que o islam devesse ser enfrentado; o que eles advertiam é que os antigos métodos, sustentados gente como Llull, eram ineficazes e mais valeria o embargo econômico do Ocidente em relação ao Oriente do que o envio inesgotável de tropas cristãs. Contudo, como dissemos, a cruzada é mais do que uma luta, é uma expressão do modo de ser eclesial no Ocidente, é parte de uma cultura religiosa de longa duração e, assim, ainda que estrategicamente os latinos pouco auferissem com essas guerras no Oriente, a euforia pela conquista não diminuía, mesmo após a tomada de Acre, em 1291. No Tractatus redigido no ano seguinte, Llull recorda ao papa a urgência da oportunidade: as pessoas estão muito tristes pela recente perda da Terra Santa, mas ficarão outra vez alegres ao ver a justeza da nova empreitada (GARÌ e REBOIRAS, 2003, p. 346).

A artimanha de Llull ao tentar convencer o papa não disfarça a sua intenção de fazer da recuperação da Terra Santa o instrumento da conversão universal dos não católicos. O método adequado para isso, como vimos, não era a guerra, mas a pregação, pois no reordenamento do mundo devia-se seguir o princípio de sua salvação:

quando a pregação e a devoção cessaram, surgiu Maomé que fingia ser profeta, e assim ele e seus sequazes destruíram quase a metade dos cristãos, e ainda os destroem. Donde convém que seja feito conforme a ordem predita. E porque os Sarracenos ocupam a terra da igreja dos cristãos, é lícito que eles os enfrentem e recuperem as terras que possuem injustamente. (GARÌ e REBOIRAS, 2003, p. 345).

A fé iniciou-se pela pregação; sua interrupção ocasionou o avanço dos inimigos. Pela pregação se pode recuperar não só os antigos espaços, mas também 
seus novos moradores. A luta é lícita como ato de defesa e em vista da reocupação do que se possuía; é também lícita se, por ela, for garantida a propagação da fé, pelos pregadores e pelos soldados de Cristo, os membros das Ordens militares, sobretudo a Ordem da Milícia, a qual deveria ter, nos planos de Llull, um papel eminentemente missionário.

Todavia, independentemente das motivações apresentadas por cristãos como Llull, a concepção de uma Ordem religiosa militar ou até mesmo de guerra santa, amiúde, são entendidas pelos especialistas e pelos crentes atuais como um desvio de conduta de um suposto pacifismo originário cristão ou ainda, o que é pior, como uma contaminação do universo religioso pela política, entendendo, dessa forma, que a comunidade cristã ideal não teria tido - ou não deveria ter - compromissos com os poderes seculares, sobretudo, com seus interesses supostamente mundanos.

Por outro lado, pensar a guerra e, por conseguinte, a violência, como constitutiva do ethos cristão não é operação comum nem mesmo para historiadores não confessionais; como lembra Philippe Buc (2015, p. 70-71), os grandes especialistas do século XX, como Schmuel Eisenstadt, Eric Voegelin, Carl Erdmann, James Russel, Jean Flori e Jonathan Riley-Smith, partem do pressuposto de que o cristianismo era originariamente pacífico e leem a violência cristã como degenerescência de seus fundamentos, cujas causas devem ser buscadas fora da própria experiência religiosa. Referindo-se às cruzadas, Colin Morris (1998, p. 201), por exemplo, chamava-as de "o câncer do corpo da cristandade medieval". Seria interessante procurar entender o peso da visão negativa que o conceito de Idade Média exerceu sobre as interpretações que estes eruditos produziram; autores como Erdmann, Russel e Flori acreditam que, após o Ano Mil, houve algo como uma quebra de paradigma na história do cristianismo que o tornou fundamentalmente violento e, em minha opinião, esta forma de ver não está apenas atrelada às variações teóricas do mutacionismo, como definido por Dominique Barthélemy (2003, p. 219), mas avança para interpretações mais antigas (e talvez mais distorcidas) da história do próprio cristianismo e que se ligam a um conceito problemático de 'Idade Média'. 
Ora, o que se procurou mostrar com o caso de Ramon Llull é justamente o contrário. A cristandade latina era militante e, nesse sentido, guerreira, não por desvio de índole ou depravação (medieval!) de sua história, mas porque era oriunda da somatória histórica de comunidades políticas que, identificadas por uma fé cristã inculturada, se afirmavam como sociedades de guerra (LOURIE, 1966, p. 54); referindo-se aos Francos carolíngios, núcleo primário desta eclesialidade militante, Regine Le Jan os chamava de “povo em armas” (LE JAN, 2011, p. 29).

O que quero ressaltar é que, a despeito das idealizações teológicas dos cristãos (de ontem e de hoje), não se pode deduzir, sem anacronismo e distorção, um cristianismo como categoria universal imutável; o que identificamos, do ponto de vista da historiografia, são comunidades cristãs enxertadas em tempos/espaços específicos, que, ora respondem aos apelos destes tempos/espaços, ora reproduzem estes apelos, pois as comunidades cristãs não descem do céu, mas se formam em reais experiências históricas. Deste modo, não existe fé cristã senão enraizada numa precisa cultura política que não pode ser ignorada quando se trata de analisar suas expressões históricas; tais comunidades cristãs (antigas, medievais e mesmo modernas), antes de serem manifestações de uma religião universal, são produtos de sociedades concretas, cujo sentido, muitas vezes, é estabelecido por um conjunto de crenças que não existiria sem a ossatura da própria sociedade.

Ademais, o problema da violência cristã é tanto mais grave porque está na base do repúdio histórico 'moderno' pelo período justamente chamado de 'medieval', pois distante daquela fé que se acreditava pura na 'antiguidade' e superado por uma radical separação, inventada pelos próprios cristãos, entre Igreja e Estado, reivindicada pelos regimes liberais. Daí deriva a tendência de, por um lado, destacar, na história medieval, as figuras e acontecimentos que denunciavam a violência guerreira como “câncer social” e, de outro lado, de não encarar a violência como 
conceito aberto e flexível, neste caso, como estratégia adicional do jogo político ${ }^{23}$.

A análise dos propósitos de Ramon Llull em relação à missão e ao triunfo da fé cristã sobre a terra faculta perceber que a natureza agonística do cristianismo do primeiro milênio não desapareceu no segundo, embora tenha encontrado formas mais inculturadas e, portanto, diversas, de manter sua força significativa e identitária. A possibilidade ou, ao menos, a inevitabilidade da guerra (justa ou santa, pouco importa) existe no fundamento da comunidade, ainda que esta possibilidade, no limite, dependa de um rasgo no tempo e de uma superação da história, como sugere a literatura apocalíptica cristã, antiga e medieval, para a qual o mundo vindouro - ou o reino de Deus - depende inexoravelmente da guerra suprema do bem contra o mal.

\section{REFERÊNCIAS}

ALBERTE, A. Retórica medieval. História de las artes predicatorias. Madri: Centro de Linguistica Aplicada/Atenea, 2003.

AMORETTI, B. S. Il mondo musulmano. Quindici secoli di storia. Roma: Carocci Editore, 1998.

AYALA MARTÍNEZ, C. Reconquista, cruzada y órdenes militares. Bulletin du Centre d'Études Médiévales d'Auxerre - BUCEMA [en ligne], Auxerre, n. 2, 2008. Disponível em: <http://cem.revues.org/9802>. Acesso em: 30 mar. 2017.

BARTHÉLEMY, D. A cavalaria. Da Germânia antiga à França do século XII. Campinas: Editora da Unicamp, 2010.

BARTHÉLEMY, D. Un cambio de milenio sin transformaciones radicales. In: LITTLE, L.; ROSENWEIN, B. (org.). La Edad Media a debate. Madri: Ediciones Akal, 2003, p. 219238.

BATLLORI, M.; CALDENTEY, M. Ramon Lull. Obras Literarias. Libro de Caballería, Blanquerna, Felix, Poesias. Madri: Biblioteca de Autores Cristianos, 1948.

\footnotetext{
${ }^{23}$ Superar estas distorções nem sempre é fácil, mas é necessário. Mesmo as origens cristãs foram marcadas por discursos e práticas "violentos", por exclusões e preconceitos étnico-religiosos que, em diversas ocasiões, geraram dor e morte. No que tange ao cristianismo primitivo, Philippe Buc (2015, p. 70) distingue dois sentidos na literatura neotestamentária: o sentido exotérico (que se refere às relações com o mundo externo e expõe as ideias sobre este mundo) e um sentido esotérico (que se refere ao pensamento interno, muitas vezes dissimulado, em relação ao mundo); assim, os Evangelhos Sinóticos não permitem associar Jesus ou seus discípulos a nenhuma luta armada propriamente dita (significado exotérico), mas admitem a existência de uma luta entre as forças de Deus e as forças satânicas, luta essa que, no final dos tempos, receberá contornos apocalípticos (significado esotérico).
} 
BUC, Ph. Holy War, Martyrdom, and Terror. Christianity, Violence, and the West. Filadélfia: Pennsylvania University Press, 2015.

CARRAZ, D. L'Ordre du Temple dans la Basse Vallée du Rhône (1124-1312).

Ordres militaires, croisades et sociétés méridionales. Lyon: Presses Universitaires de Lyon, 2005 .

COCCIA, E. "Inobedientia" o pecado de Adão e a Antropologia judaico-cristã. Signum Revista da ABREM, Belo Horizonte, v. 17, n. 1, p. 310-331, 2016.

COHN, Norman. A Conspiração mundial dos Judeus: Mito ou Realidade. São Paulo: Ibrasa, 1969.

CONEDERA, S. Ecclesiastical Knights. The Military Orders in Castile, 1150-1330. Nova Iorque: Fordham University Press, 2015.

COWDREY, H. The Mahdia Campaign of 1087. In: CONGDON, E. (org.). Latin Expansion in the Medieval Western Mediterranean. Londres/Nova Iorque: Routledge, 2013, p. 1-30.

CRESPO, P. Documentos para el estudio de las Órdenes Militares en España. Revista Xiloca (Centro de Estudios del Jiloca), Calamocha, v. 34, p. 185-214, 2006 a.

CRESPO, P. La fundación de Monreal del Campo. In: GIMENO, E. B. (org.). Historia de Monreal del Campo. Calamocha: Centro de Estudios del Jiloca, 2006b, p. 35-46.

DE MAS LATRIE, L. Traités de paix et de commerce: et documents divers concernant les relations des chrétiens avec les Arabes de l'Afrique septentrionale au Moyen Âge [suivi de suppléments et tables publiés em 1872]. Paris: H. Plon, 1866-1872.

DELARUELLE, E. Essai sur la formation de l'idée de croisade. Bulletin de Littérature Ecclésiastique, Toulouse, v. 42, p. 24-103, 1941.

ENSENYAT, G. Pacifismo y cruzada en Ramon Llull. Quaderns de la Mediterrània, v. 9, p. 354-36o, 2008.

FERRA, M. Ramon Llull Libre de Contemplació en Deu escrit a Mallorca e transladat darabic em romanç vulgar devers lany M.CC.lxxij. In: FERRA, M.; GALMÉS, S.; OBRADOR Y BENNASSAR, M. (ed.). Obres de Ramon Lull Edició original feta en vista dels millors y més antichs manuscrits. Volume IV, Tomo III. Palma de Mallorca: Comissió Editora Lulliana, 1910.

FERRER MALLOL, M. T. Frontera, convivencia y proselitismo entre cristianos y moros en los textos de Francesc Eiximenis y de San Vicente Ferrer. In: SOTO RÁBANOS, J. M. (org.). Pensamiento medieval hispano. Homenaje a Horacio Santiago-Otero. Madri: CSIC, 1998, p. 1579-1600.

FLORI, J. A cavalaria. A origem dos nobres guerreiros da Idade Média. Trad.: Eni Tenório dos Santos. São Paulo: Madras, 2005.

FLORI, J. Guerra Santa. Formação da ideia de cruzada no Ocidente cristão. Trad.: Ivone Benedetti. Campinas: Editora da Unicamp, 2013. 
GARÍ, B.; DOMÍNGUEZ REBOIRAS, F. (ed.). Liber de Sancta Maria in Monte Pessulano anno MCCXC conscriptus, CVI Liber de Passagio Romae anno MCCXCII compositus necnon Brevis Notitia Operum aliorum incerto tempore ac loco perfectorum adnectuntur. Raimundi Lulli Opera Latina 49-52. Turnhout: Brepols, 2003.

GROSSI, P. Da sociedade de sociedades à insularidade do estado entre medievo e idade moderna. Revista Seqüência, Florianópolis, v. 55, p. 9-28, 2007.

GUÉRARD, M. Cartulaire de l'Abbaye de Saint-Victor de Marseille. Tome I. Collection des Cartulaire de France, Vol. VIII. Paris: Typographie de Ch. Lahure, 1857.

IOGNA-PRAT, D. La invención social de la Iglesia en la Edad Media. Trad. Espanhola: Ángela Schikler e Silvia Tenconi. Buenos Aires: Miño y Dávila, 2016.

IOGNA-PRAT, D. Order and exclusion: Cluny and Christendom face heresy, Judaism, and Islam, 1000-1150. Nova Iorque: Cornell University Press, 2002.

JAULENT, E. Raimundo Lúlio: um único pensamento e um único amor. São Paulo: Instituto Brasileiro de Filosofia e Ciência "Raimundo Lúlio", 2013.

JOHNSTON, M. D. The Evangelical Rhetoric of Ramon Llull: lay learning and piety in the Christian West around 1300. Nova York: Oxford University Press, 1996.

JOSSERAND, Ph. Croisade et reconquête dans le royaume de Castille au XIIe siècle. Éléments pour une réflexion. In: CRESSIER, P.; BOUCHERON, P.; MORNET, É. (org.). L'Expansion occidentale (XIe-XVe siècles). Formes et conséquences. Paris: Publications de la Sorbonne, 2002, p. 75-85.

KING, M. Perceptions of Islam in the Carmen in Victoriam Pisanorum. Hortulus - The Online Graduate Journal of Medieval Studies, Groningen, v. 11, n. 2, 2015. Disponível em: <https://hortulus-journal.com/king/>. Acesso em: 30 mar. 2017.

KINZLE, B. M. Cistercians, Heresy and Crusade in Occitania (1145-1229). Preaching in the Lord's Vineyard. Suffolk/Nova Iorque: New York Medieval Press, 2001.

KINZLE, B. M. Introduction. In: KINZLE, B. M. (org.). The Sermon. Turnhout: Brepols, 2000, p. 143-174.

LE JAN, R. A ideologia do poder no reino dos francos. In: ALMEIDA, N. B.; SILVA, M. C. (org.). Poder e construção social na Idade Média. História e Historiografia. Goiânia: Editora UFG, 2011, p. 19-46.

LE MYÉSIER, Thomas. Breviculum ex artibus Raimundi Lulli electum. 1322. Disponível em: <http://digital.blb-karlsruhe.de/blbhs/content/titleinfo/98149>. Acesso em: 03 dez. 2016

LEOPOLD, A. R. Crusading proposals of the late thirteenth and early fourteenth centuries. Durham: Durham University, 1998. Disponível em: <http://etheses.dur.ac.uk/977/>. Acesso em: 30 mar. 2017. 
LLULL, R. Raimundo Lúlio e as Cruzadas. Liber de Passagio, Darrer Llibre sobre la Conquesta de Terra Santa, Liber de Acquisitione Terrae Sanctae. Rio de Janeiro: Sétimo Selo, 2009.

LOURIE, E. A society organized for War: Medieval Spain. Past and Present, Oxford, v. 35, p. 54-76, 1966.

LUCKEN, Ch. Les Sarrasins ou la malédiction de l'autre. Médiévales en ligne,

Vincennes, v. 46, 2004. Disponível em: <http://medievales.revues.org/1600>. Acesso em: 30 mar. 2017.

MAIER, C. T. Crusade Propaganda and Ideology. Model sermons for the Preaching of the Cross. Cambridge: Cambridge University Press, 2000.

MAIER, C. T. Crusading in the Age of Joinville (resenha). Speculum, Cambridge, v. 82, n. 2, p. 485-486, 2007.

MERINO, J. A. Historia de la Filosofia Franciscana. Madri: Biblioteca de Autores Cristianos, 1993.

MORIS, H.; BLANC, E. Cartulaire de l'Abbaye de Lérins publié sous les auspices du Ministère de l'Instruction Publique. Première Partie. Paris: H. Champion Libraire-Éditeur, 1883.

MORRIS, Colin. Picturing the crusades: the uses of visual propaganda, c. 1095-1250. In: FRANCE, John; ZAJAC, William (org.). The Crusades and their sources. Essays presented to Bernard Hamilton. Aldershot/Hampshir: Ashgate, 1998, p. 195-216.

MURPHY, J. J. La retorica nel Medioevo: una storia delle teorie retoriche da s. Agostino al Rinascimento. Barra: Liguori Editore, 1983.

NIRENBERG, D. Comunidades de violencia. La persecución de las minorías en la Edad Media. Trad.: Antoni Cardona. Barcelona: Ediciones Península, 2001.

PARDO PASTOR, J. Mahoma y el Anticristo en la obra de Ramon Llull. Anales del Seminario de Historia de la Filosofia, Madri, v. 22, p. 159-175, 2005.

PITRA, J. B. Analecta Novissima Spicilegii Solesmensis altera Continuatio. Tomo II. Paris: Ex Typis Tusculanis, 1888.

REYNOLDS, S. Government and community. In: LUSCOMBE, D. (org.). The New Cambridge Medieval History (volume IV parte I). Cambridge University Press: 2006, p. 86-112.

RÍOS, M. De la Restauración a la Reconquista: la construcción de un mito nacional (Uma revisión historiográfica. Siglos XVI-XIX). En la España Medieval, Madri, v. 28, p. 379$414,2005$.

RUBENSTEIN, J. Armies of Heaven. The First Crusade and the Quest for Apocalypse. Nova Iorque: Basic Books, 2011. 
SÁNCHEZ, M. A. Todo vale para construer un sermón: microtextos en la predicación castellana medieval. Revista de Poética Medieval, Alcalá de Henares, v. 23, p. 247-266, 2009.

SÁNCHEZ, M. A. Vernacular preaching in Spanish, Portuguese and Catalan. In: KIENZLE, B. (org.). The Sermon. Turnhout: Brepols, 2000, p. 759-857.

SCHWARTZ, S. B. Cada um na sua lei. Tolerância religiosa e salvação no mundo atlântico ibérico. Trad.: Denise Bottman. São Paulo/Bauru: Companhia das Letras/Edusc, 2009.

SERVENTI, S. La parole des prédicateurs. Indices d'oralité dans le reportationes dominicaines (XIVe-XVe siècle). Cahiers de recherches médiévales et humanistes, Paris, v. 20, p. 281-299, 2010.

SIDDIQ, M. Y. Epigraphy and Islamic Culture. Inscriptions of the early Muslim rulers of Bengal (1205-1494). Nova Iorque: Routledge, 2016.

SORIA FLORES, A. (ed.). Raimundi Lulli Opera Latina. 118: Liber de Praedicatione distinctio II B Centum Sermones. Palma de Maiorca: Maioricensis Schola Lullistica, 1963.

TYERMAN, Chr. A Guerra de Deus. Uma nova História das Cruzadas. Trad.: Alfredo Barcelos Pinhiero. Rio de Janeiro: Imago, 2010. Vol. 1.

TYERMAN, Chr. What the Crusades meant to Europe. In: LINEHAN, P.; NELSON, J. L. (org.). The Medieval World. Nova Iorque: Routledge, 2007, p. 131-145.

VONES, L. Mission et frontière dans l'espace Méditerranéen: tentatives d'une société guerrière pour la propagation de la foi. In: ARMSTRONG, G.; WOOD, I. (org.).

Christianizing Peoples and Converting Individuals. Turnhout: Brepols, 2000, p. 203-222.

WICKHAM, Chr. The Inheritance of Rome. Illuminating the Dark Ages, 400-1000. Nova Iorque: Penguin Books, 2009. 